\title{
History of whaling in Annobón, Equatorial Guinea, and new evidence of its continued occurrence
}

\author{
Russell Fielding ${ }^{1}$ and Christian BarRientos ${ }^{2}$ \\ Contact e-mail: rfielding@coastal.edu
}

\begin{abstract}
A regular, though infrequent, artisanal whaling operation targeting humpback whales has been known to occur from the West African island of Annobón, Equatorial Guinea, since the late $18^{\text {th }}$ century. Little has been known outside of Equatorial Guinea about this whaling operation since the mid-1970s. This paper presents a brief history of Annobonés whaling and describes recently surfaced video-recorded evidence of its continuation into the $21^{\text {st }}$ century. In this video, two humpback whales (likely a mother-calf pair) are in the process of being hunted by whalers in a flotilla of small whaling vessels. While the capture and death of the whales is not part of the recording, it appears likely that at least the calf was eventually taken. The paper concludes with a consideration of the future of the Annobonés whaling operation and an urgent call for more research.
\end{abstract}

KEYWORDS: AFRICA; ATLANTIC OCEAN; BREEDING GROUNDS; CONSERVATION; DIRECT CAPTURE; HUMPBACK WHALE; WHALING-HISTORICAL; WHALING-MODERN; WHALING-SMALL TYPE

\section{INTRODUCTION}

Annobón (also known as Pagalu) is a $17 \mathrm{~km}^{2}$ island with a 2015 population of 5,232, located in the South Atlantic Ocean near the Gulf of Guinea ${ }^{3}$ (Instituto Nacional de Estadística de Guinea Ecuatorial, 2015). Annobón is one of the seven provinces of the West African nation of Equatorial Guinea, though geographically separated from the country's other provinces by the independent two-island nation of São Tomé and Príncipe (Fig. 1). Volcanic in origin, but extinct, Annobón is the southwesternmost island in the Cameroon Line: a chain of oceanic and continental volcanoes stretching $1,800 \mathrm{~km}$ to Lake Chad (Déruelle et al., 1991). The Equator passes just north of Annobón and the entire region is characterised by a tropical climate, primarily Aw in the Köppen-Geiger classification scheme (Beck et al., 2018). The region's oceanography is dominated by the Guinea Current, this current's associated zones of upwelling (Bakun, 1978), and freshwater inputs from the Volta, Niger and Ogooué rivers. The nutrient availability resulting from these sources contributes to the Gulf of Guinea's productivity as a fishing ground and attracts migrating cetaceans to the region (de Boer et al., 2016). Southern Hemisphere humpback whales (Megaptera novaeangliae) of the International Whaling Commission (IWC)-identified B1 breeding stock migrate to the Gulf of Guinea for breeding and calving during the austral winter (Bamy et al., 2010; Carvalho et al., 2011; Collins et al., 2008; Picanço et al., 2009; Rosenbaum and Collins, 2006; Van Waerebeek et al., 2009; Weir, 2011).

Annobón was described as being uninhabited when discovered, first by the Spanish in 1470, then by the Portuguese on 1 January 1473 - the date from which its name is derived, ano bom being Portuguese for 'good

${ }^{1}$ Coastal Carolina University, USA.

${ }^{2}$ Wildlife Conservation Society, Equatorial Guinea.

${ }^{3}$ While commonly referred to as being located 'in' the Gulf of Guinea, Annobón's position is technically just south of the Gulf's southern border (as defined by the International Hydrographic Organization, 1953). 


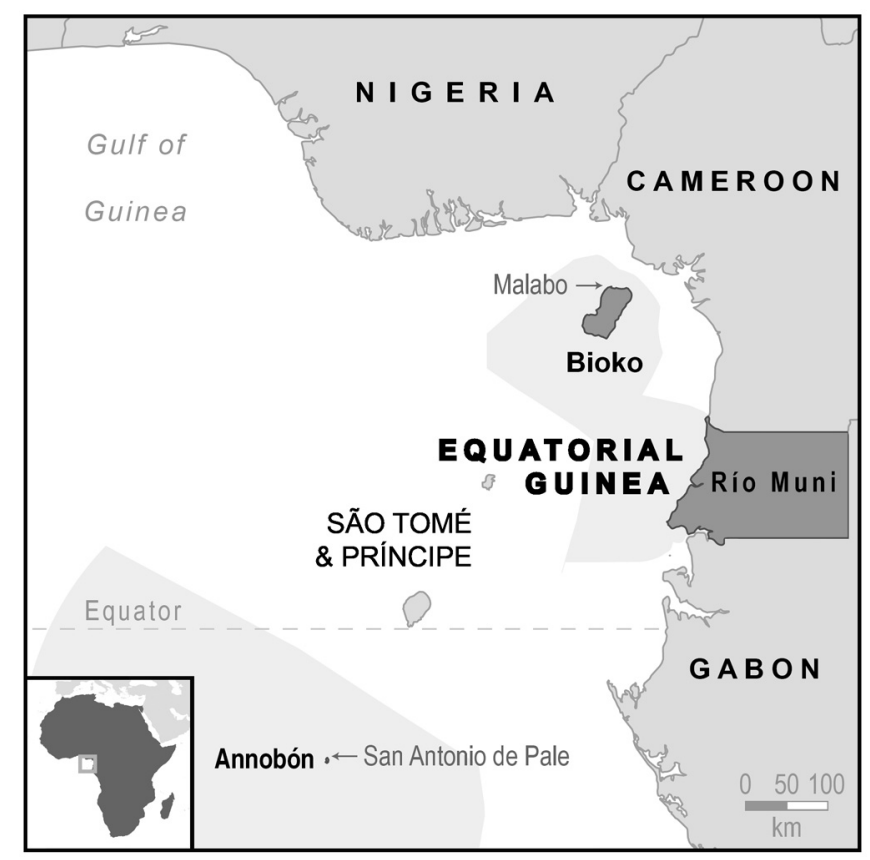

Fig. 1. Map showing location of Annobón within Equatorial Guinea and the Gulf of Guinea. Cartography by A. Ollivierre, Tombolo Maps and Design.

year'. The island was used as a waystation during the Atlantic slave trade; its current population is largely descended from the enslaved Angolans and São Toméans that the Portuguese transported there (Skutsch, 2013). In 1778, most of what is now Equatorial Guinea became the Spanish colony of Guinea Española as determined by the Treaty of El Pardo (Rodríguez-Fonesca and Garita-Alpízar, 2013). Colonial rule ended in 1968 when the independent state of Equatorial Guinea was founded. Since then a single-party government that replaced the Spanish colonialists has held power (Warf, 2019). Equatorial Guinea is the only independent African country in which Spanish is an official language, though a Portuguese creole known as Fá d'Ambô is spoken more commonly among Annobonés (Hagemeijer and Zamora, 2016).

\section{WHALING HISTORY}

American and European whaling vessels began taking humpback whales and occasionally sperm whales (Physeter macrocephalus) in the Gulf of Guinea during the $18^{\text {th }}$ century. Their logbook records were painstakingly charted by Townsend (1935), showing a concentrated effort during the austral winter months, when Antarctic-feeding humpback whales migrate to the Eastern Tropical Atlantic to breed and calve (Van Waerebeek et al., 2001; Weir, 2011). During the early $20^{\text {th }}$ century, vessels mainly from Norway and Spain began whaling in the area, based out of ports in Gabon, Guinea Española and São Tomé. The First and Second World Wars interrupted foreign whaling in the region. When international whaling in the Gulf of Guinea resumed in the late 1940s, catches began to decline. This decline continued to the point that commercial whaling in the Gulf of Guinea had essentially ceased by 1959, four years before the International Whaling Commission (IWC) moratorium on Southern Hemisphere whaling went into effect in 1963 (Aguilar, 1985).

Likely through their association with foreign whalers, local Annobonés began whaling no later than the late $19^{\text {th }}$ century. Spanish missionaries arriving at Annobón in 1885 found whaling to be an already-established activity there (Aguilar, 1985; Basilio, 1957). For part of the $19^{\text {th }}$ century and more than half of the $20^{\text {th }}$ century, foreign commercial and local artisanal whaling coexisted in the waters surrounding Annobón. When commercial whaling ceased, only locally directed, shore-based artisanal whaling remained.

This scenario parallels that of Bequia, a Caribbean island where whaling was introduced during the $19^{\text {th }}$ century through the recruitment of local labour aboard American whaling vessels, and that today supports an 
IWC-sanctioned aboriginal subsistence take of humpback whales (Adams, 1971; Hamaguchi, 2005; Ward, 1995). The major difference between Annobón and Bequia, however, is that the whaling operation based at Bequia is internationally regulated and reasonably well-studied while its counterpart based at Annobón is obscure on the international stage and regulated only by local laws and customs. Bequia is part of St. Vincent \& the Grenadines, which is an IWC member state; Annobón is part of Equatorial Guinea, which is not.

The most thorough cultural and environmental analysis of Annobonés whaling is Aurelio Basilio's Caza y Pesca en Annobón (Hunting and Fishing in Annobón), published in Spanish in 1959. This broad overview of animalbased food production methods practiced on Annobón devotes more than half of its pages to whaling in a long chapter titled 'La Pesca de la Ballena' ('Whale Fishing'). Basilio was a Catholic priest based on the island of Fernando Pó (now called Bioko) who made extensive studies of the region's natural history (e.g. Amadon and Basilio, 1957; Basilio, 1962; 1963). Basilio's rich description of Annobonés whaling, as well as the photographic plates included in his 1959 book, inform the reader about the practice. Basilio indicates that the whaling season consisted only of the months of July and August and that humpback calves were the primary target of the operation. He describes the main product as food for local consumption, as opposed to oil, which was the major commodity produced by the Gulf of Guinea commercial whaling operations (Aguilar, 1985; Basilio, 1957).

Similar cases of occasional humpback whale takes have been documented in other nations in the Gulf of Guinea, which may be inspired by the Annobonés example. These include two humpback whale calves captured for human consumption in Cameroon (Ayissi et al., 2011) and two cases of 'stranded' calves, either alive or freshly dead, in Togo and Ghana that most probably were butchered for food. In Ghana, a significant market exists for small cetaceans sold as marine bushmeat (Van Waerebeek et al., 2009).

When Equatorial Guinea gained independence in 1968, the new government began a period of isolationism during which vestiges of the former colonial system were abandoned. Many foreigners, including Basilio, were expelled in the years following the rise of the new government in 1970 (Beolens et al., 2009). The observation and analysis of Annobonés whaling by researchers publishing in the international academic press since that time has been 'fragmentary and inconsistent' (Aguilar, 1985, p.386). Aguilar's study on the subject revealed whaling activities taking place from Annobón as recently as 1975 but was only able to suggest that Annobonés whaling probably still occurs at the time of writing in 1985 (p.386). Subsequent publications either referred back to Aguilar (1985) or speculated that whaling might still occur as late as 2012 (Fielding, 2018; Robards and Reeves, 2011; Weir and Pierce, 2012).

In the years leading up to the IWC's 1986 moratorium on commercial whaling, popular perceptions of whaling began to shift toward placing the activity into a bygone era. Popular authors and even some scholars began to describe existing whaling operations as 'the last' of their kind (e.g. Adams, 1994; Clark, 2019; Johnson, 2000; Neufield, 1973; Smith, 2013; Weston, 2014). Other scholars have criticised this, showing instead that whaling and small cetacean exploitation remain popular methods of food production in many areas around the world (Robards and Reeves, 2011) and that, in some regions, whaling activities - particularly artisanal operations conducted primarily for food - are increasing in response to shortages from other food production sectors as well as commercial considerations (Clapham and van Waerebeek, 2007). Despite the inappropriateness of its broad application, during the past few decades it has appeared, until now, as though the 'last whalers' descriptor may have accurately described the $20^{\text {th }}$ century Annobonés.

\section{NEW EVIDENCE FOR $21^{\text {ST }}$ CENTURY ANNOBONÉS WHALING}

In December 2019, an amateur video surfaced, which provides evidence of the continued, recent practice of Annobonés whaling. While the precise date of the events depicted in the video is difficult to ascertain, some clues exist. The filename of the video is '17-11-06 Annobón Pesca Ballena.mp4,' ('17-11-06 Annobón Whale Fishing', in Spanish). The filename appears to indicate the date of this 'Whale Fishing' but its interpretation is somewhat ambiguous. In determining the date, we must first acknowledge that the individual who provided the video to us reported that the events it depicts took place in 2018 (Fernando Evuna, Annobón Reserve Manager, pers. comm. to C. Barrientos). Contrary to this report, if the filename is meant to indicate a date, and if that date is presented in the standard Spanish format (day-month-year) (Kaplan, 2011), it would indicate a date of 17 
November 2006. Another possible interpretation of the filename as a date is 6 November 2017 (year-monthday). While nonstandard in Spanish usage, this dating convention would allow for chronological/alphabetical sorting if, for example, the video file was kept in a folder along with other video files dated in the same way. Another possible interpretation of the filename as a date is 11 June 2017 (day-year-month) but this is unlikely, given the timing of migration patterns of humpback whales between the Antarctic and the Gulf of Guinea (Carvalho et al., 2011; Rosenbaum and Collins, 2006; Van Waerebeek et al., 2001; Weir, 2011).

If we put aside the possibility of the filename indicating a date, other evidence for establishing the earliest possible date of the events can be found in the video's format and content. The mpeg- 4 video format, a standard for video-capable mobile phones, was introduced in 1998 (Pereira and Ebrahimi, 2002) and while its availability in West Africa came much later, as did widespread internet (Fuchs and Horak, 2008) and mobile phone coverage (Aker and Fafchamps, 2015) that year can be taken as an absolute earliest date for the events depicted in the video if we assume that $\mathrm{mp} 4$ is its original format. The most compelling evidence for setting an earliest possible date, however, comes in the form of attire worn by one of the more prominent whalers in the video. This man appears to be wearing a replica FC Barcelona football (soccer) jersey with its distinctive vertical blaugrana (blue and maroon) stripes and yellow collar. The yellow collar on this jersey was introduced in 2010 - prior to then, Barcelona's blaugrana jerseys included non-contrasting collars (Football Kit Archive, 2020). Thus, if we assume the man obtained his replica jersey in the same year it was introduced, 2010 becomes the earliest possible year for the whaling events depicted in the video. If the jersey arrived in Equatorial Guinea as part of the thriving trade in secondhand clothing between Europe and Africa (Valenciano-Mañé, 2017), the earliest possible date would be later.

In terms of biological and historical evidence, a November date would be more likely than June, given the seasonality of humpback whale presence in the Gulf of Guinea. Previous research has found the peak abundance of humpback whales in the region to occur either between July and September (Rosenbaum and Collins, 2006) or between early August and early November (Van Waerebeek et al., 2001). Mother-calf pairs appear to remain in the area latest into the year, with sightings occurring well into November (Carvalho et al., 2011). The history of Annobonés whaling (Aguilar, 1985; Basilio, 1957) and in the Gulf of Guinea more generally (Townsend, 1935) shows similar seasonality.

We acknowledge, therefore, a range of possible dates for the events depicted in this video-recording from 2010 at the earliest (the introduction of the yellow-collared FC Barcelona jersey) to 2018 at the latest (the year reported to us by the source of the video-recording) with 6 November 2017 most likely. We choose this date as the most likely owing to its accommodation of the assumptions that the filename includes a date but makes use of a nonstandard dating convention and that the video's source possibly misremembered the year, while remaining constrained by the introduction of the yellow-collared FC Barcelona jersey and the known seasonality of humpback whale presence in the region. Future evidence may change opinion on this.

This four minute, nineteen-second video appears to have been taken from a boat that was part of a flotilla just offshore from Annobón. The sky is overcast, and the coastline is clearly visible with unique topographic features and the village of San Antonio de Pale clearly indicating that the setting is indeed off the coast of Annobón (Fig. 2). At least seven other boats are visible, mainly dugout-style pirogues, most of which are propelled by oars but including at least one with an outboard motor mounted at the stern. Each boat carries one-to-four men (only men). Most of the men seen in the boats are wearing casual, athletic clothing but a few appear to be in foul-weather gear.

Whaling activities are clearly already underway when the video begins, as it shows a humpback whale surfacing very close to one boat within the first four seconds. At about 00:20, a second whale surfaces (Fig. 3), noticeably smaller than the first (likely a neonate or juvenile calf), which would indicate that the practice of approaching mother-calf pairs and taking the calves is still current. The smaller whale appears to have already been struck by a harpoon before its first appearance on screen, as a short length of metal bar (attached to a line) protrudes from its dorsal area just forward of the blowhole. At about 00:30, a man in a pirogue thrusts another harpoon into the calf, striking it very close to the location where the previous one is attached. Blood becomes visible in the whale's spout. The man who drove in this harpoon then stands in the bow of his boat and uses 


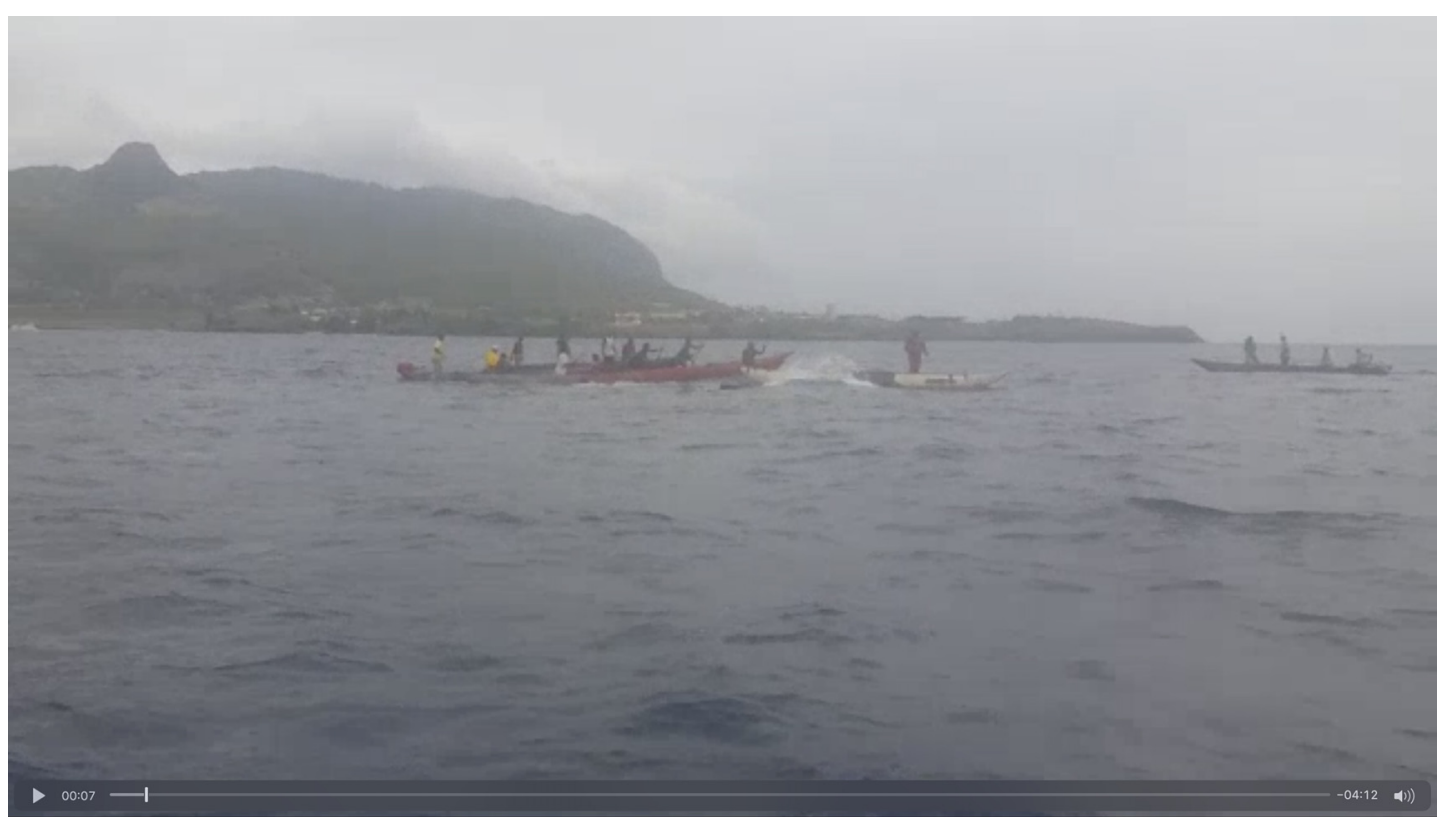

Fig. 2. Still image taken from the video-recording under discussion here. This image shows the coastline of Annobón, recognisable by its topography and structures.

what appears to be a half-meter piece of lumber to 'hammer' the harpoon deeper into the whale by striking the base of its shaft (Fig. 4). While techniques to drive harpoons deeper into the flesh of whales have ranged from the use of explosively-charged harpoon cannons to the harpooner's own body weight (Johnson, 2000), we are unfamiliar with the practice of striking a harpoon to hammer it into a whale occurring anywhere else. This practice was probably adopted - as opposed to the use of even rudimentary harpoon guns, as is common among Caribbean whalers (Fielding, 2018) - because of government-placed limits on civilian access to explosives or weapons in Equatorial Guinea.

The harpoons themselves appear to be approximately two meters in total length. Each is comprised of a long wooden shaft and shorter metal fore-shaft. Barbed harpoon heads are visible, though it is impossible, owing to

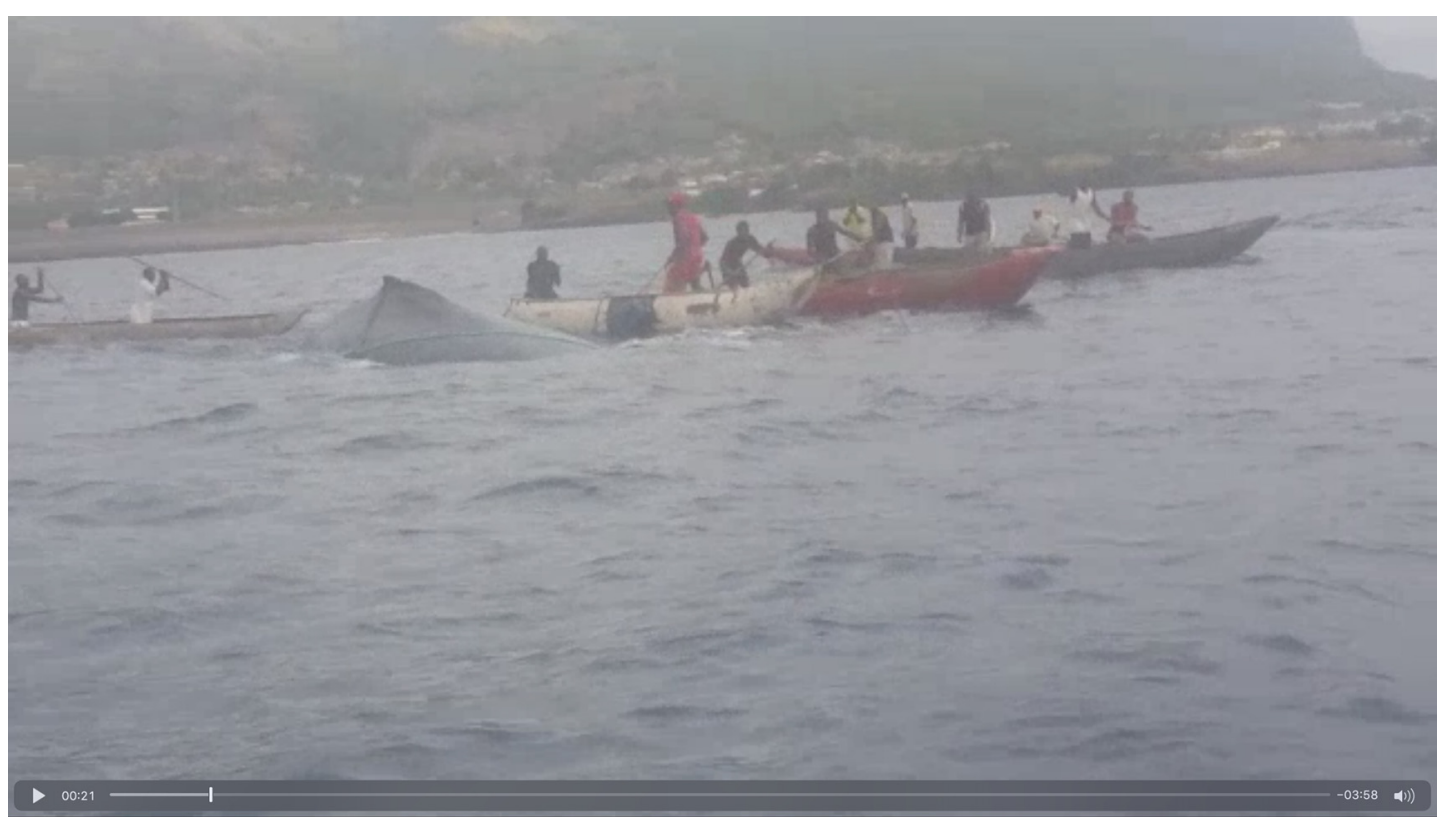

Fig. 3. Still image taken from the video-recording under discussion here. This image shows a humpback whale, recognisable by its dorsal anatomy, surfacing near a flotilla of pirogues from which it is being hunted. 


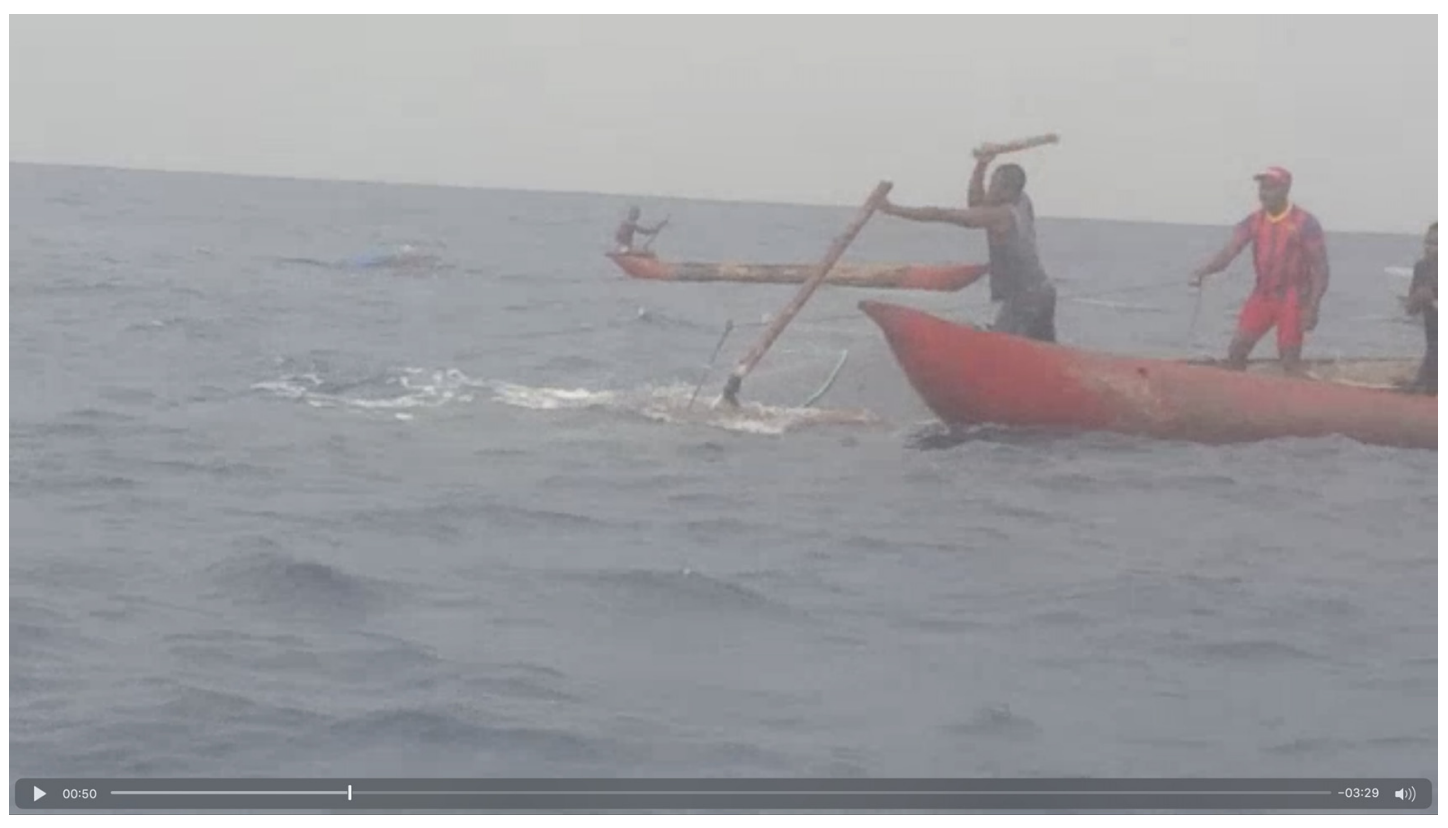

Fig. 4. Still image taken from the video-recording under discussion here. This image shows a whaler in the act of using a piece of lumber to 'hammer' a fast harpoon deeper into the whale. Note that the man wearing the FC Barcelona jersey is also visible in this image.

the video quality, to tell whether these are fixed or toggling. Some, such as the one already embedded in the whale at the commencement of the video, seem to lack the wooden shaft and are comprised of a metal shaft attached directly to a line tied through a round eye at the base.

At 01:07, the same harpooner throws a third harpoon into the whale. This one features a much shorter shaft (about one meter) and is attached to a woven strap rather than a line. About this same time, men in other boats - including, perhaps, the same boat as the person holding the camera, as their voices are very clear - repeatedly shout 'Mata a dos!' (Kill two! in Spanish). The authors understand this to be an encouragement to take both whales, either the mother and calf or the already-harpooned calf and another, unseen whale. The shorter harpoon does not hold fast in the whale; the harpooner retrieves it by hauling in the strap and immediately thrusts it down again where it appears to hold. For the next several seconds of video, the camera is inadvertently trained on the surface of the sea, but the audio indicates that the same 'hammering' process is used to further drive in the shorter harpoon.

At 01:34 the larger humpback whale surfaces to breathe and swims several meters ahead of the harpooner's boat. The smaller whale strains at the harpoons' lines and strap to accompany the larger whale and the men aboard attempt to hold it back. More blood is visible near the sites of harpoon attachment. Men in the harpooner's pirogue hold to the longer harpoon's line and those in another pirogue hold to the shorter harpoon's strap; both boats are dragged along behind the whale. Men in other boats keep up with the whales by paddling. Both whales remain close together. After several seconds of inadvertent close-up footage of the hold of the camera-holder's boat, the video resumes its focus on the whaling activities. It is seen that the larger whale has swum off-screen and that several boats are clustered around the smaller whale, still held fast by the men in two boats.

At 02:57, a man in the boat now closest to the harpooned whale signals to a boat behind his. A man in that boat passes a harpoon to the man riding aft in the closest boat. This harpoon had apparently been attached to a float, as, after passing it, the man can be seen tossing a large, spherical, orange buoy into the water. The buoy is attached to the harpoon by a heavily knotted line. The man who received the harpoon leaps forward in the closest boat and, after pausing for the whale to exhale, drives the harpoon in. This second harpooner then steps partly out of the boat and places his right foot onto the whale while forcing the harpoon further into its flesh.

With four harpoons all fast in the whale, the two men in the closest boat begin leaning onto two harpoons' bases to drive them further into the whale. The amount of blood in the water visibly increases with these efforts. Suddenly, at 03:46, the larger humpback whale surfaces and exhales immediately alongside the smaller whale. 
The vocal reaction is mainly laughter, however, not surprise. The second harpooner then thrusts another shaftless harpoon into the smaller whale. As he works the harpoon deeper into the smaller whale, the larger whale continues swimming alongside it, occasionally surfacing to breathe.

The video abruptly ends at 04:19.

\section{DISCUSSION}

In any context, small-boat whaling with hand-held harpoons is a dangerous activity that carries a risk of injury or death to the whalers. Human life has occasionally been lost during whaling off Annobón; the last known whaling death occurred in 2005 (Fernando Evuna, Annobón Reserve Manager, pers. comm. to C. Barrientos). As a method of control and risk mitigation, any attempt at whaling can now only be initiated by an elder of the community, presumably someone with a better understanding of local meteorological and oceanographic conditions and someone whose longer cautious perspective can offset a community's excitement about an opportunity to attempt to take a whale. In addition to promoting safety within the whaling community, this eldercontrolled limitation on whaling could also represent a case of 'culturally embedded conservation strategies,' by which fewer whales are taken over the long term than would have been without this form of regulation (Fielding, 2018, p.192).

Other whaling operations have reduced their intensity or ceased altogether for diverse reasons. Among the most common are overextraction, the influence of anti-whaling sentiment, reduced demand resulting from changing dietary tastes and the increasing presence of environmental contaminants (Fielding, 2010). The whaling operation based at Annobón could be affected by any of these, but the remote location of the island may serve as a buffer to the effects of cultural and environmental change. At the same time, Annobón's remoteness may increase the importance of whaling to the local food system.

Equatorial Guinea's status as a non-member state of the IWC is relevant to the continuation of Annobonés whaling. Were Equatorial Guinea to join the IWC and seek an aboriginal subsistence whaling quota for the Annobón operation targeting humpback whales, they would likely look to the case of Bequia as a salient precedent. Such an arrangement would provide the Annobonés with a degree of international oversight and scientific understanding that their whaling operation currently lacks.

Membership in the IWC would also, by necessity, bring certain changes to Annobonés whaling. Most obvious are the rules regarding the taking of calves or mother-calf pairs, which has been the practice of Annobonés whalers since at least the time of Basilio (Aguilar, 1985) and, based upon our evidence, appears to remain current practice today. The IWC's rules differ slightly among the various aboriginal subsistence whaling operations of the world. Specifically, the Bequia-based operation is forbidden 'to strike, take or kill suckling calves or female whales accompanied by calves,' while the remaining aboriginal subsistence whaling operations - all found in Arctic or subarctic regions - are forbidden from taking 'calves or any whale accompanied by a calf ' (IWC, 2018). This slight difference can be interpreted as granting permission to Bequian whalers to take calves that are not suckling. If a potential Equato-Guinean aboriginal subsistence whaling quota were to be modelled after St. Vincent \& the Grenadines's existing IWC quota, the rules regarding mother-calf pairs may carry over to Annobón, thus permitting the Annobónes to continue taking non-suckling calves (but not their mothers). In this and other ways, IWC oversight may introduce elements of humane killing that the Annobónes whaling operation currently lacks.

Regardless of the international political future of Annobonés whaling, the authors recognise that an ongoing artisanal operation targeting humpback whales that, until now, was not known even to have continued since the 1970s, represents a major lacuna in the scientific understanding of whaling. The authors therefore issue an urgent call for research to better understand the cultural and ecological implications of this whaling operation and similar exploitation in other nations of the region.

\section{ACKNOWLEDGEMENTS}

The new information presented in this paper is based upon a video-recording shared with us by Annobon Reserve Manager, Fernando Evuna. We wish to express to Mr. Evuna our sincere thanks. We also thank Gregory Ruthig 
for connecting us with one another, based upon our shared interests. We thank two anonymous reviewers for comments that resulted in a better finished paper. Finally, we would like to express appreciation to all the amateur (in the classic sense of the word) naturalists around the world who, in the spirit of Aurelio Basilio, often make first reports of natural and cultural phenomena that become the basis of future scientific inquiry. The video described in this paper can be shared upon request. Please contact the first author (Fielding) for more information. All work conforms to the legal requirements of the country in which it was carried out (including holding necessary permits), including those relating to conservation and animal welfare.

\section{REFERENCES}

Adams, J.E. 1971. Historical geography of whaling in Bequia Island, West Indies. Caribb. Stud. 11(3): 55-74.

Adams, J.E. 1994. Last of the Caribbean whalemen. Natural History 103(11): 64-72.

Aguilar, A. 1985. Aboriginal whaling off Pagalu (Equatorial Guinea). Rep. Int. Whal. Commn. 35: 385-86.

Aker, J.C. and Fafchamps, M. 2015. Mobile Phone Coverage and Producer Markets: Evidence from West Africa. World Bank Econ Rev 29(2): 262-92. [Available at: $h t t p: / / h d l . h a n d l e . n e t / 10986 / 25842]$.

Amadon, D. and Basilio, A. 1957. Notes on the Birds of Fernando Po Island, Spanish Equatorial Guinea. American Museum Novitates (no. 1846), New York. 8pp.

Ayissi, I., Van Waerebeek, K. and Segniagbeto, G. 2011. Report on the Exploratory survey of cetaceans and their status in Cameroon. Paper read at 17th Meeting of the CMS Scientific Council, 17-18 November, at Bergen, Norway. [Document: UNEP/CMS/ScC17/Inf.10].

Bakun, A. 1978. Guinea Current upwelling. Nature 271: 147-50.

Bamy, I.L., van Waerebeek, K., Bah, S.S., Dia, M., Kaba, B., Keita, N. and Konate, S. 2010. Species occurence of cetaceans in Guinea, including humpback whales with southern hemisphere seasonality. Mar. Biodivers. Rec. 3(e48). 10pp.

Basilio, A. 1957. Caza y Pesca en Annobón. Instituto de Estudios Africanos, Madrid. 98pp.

Basilio, A. 1962. 1962. La Vida Animal en la Guinea Española. Instituto de Estudios Africanos, Madrid.

Basilio, A. 1963. Aves de la Isla de Fernando Poo. Editorial Coculsa, Madrid. 202pp.

Beck, H.E., Zimmermann, N.E., McVicar, T.R., Vergopolan, N., Berg, A. and E.F., W. 2018. Present and future Köppen-Geiger climate classification maps at $1 \mathrm{~km}$ resolution, Sci. Data 5:180214. [Available at: https://doi.org/10.1038/sdata.2018.214].

Beolens, B., Watkins, M. and Grayson, M. 2009. The Eponym Dictionary of Mammals. Johns Hopkins University Press, Baltimore. 592pp.

Carvalho, I., Brito, C., Dos Santos, M.E. and Rosenbaum, H.C. 2011. The waters of São Tomé: a calving ground for West African humpback whales? Afr. J. Mar. Sci. 33(1): 91-97.

Clapham, P. and van Waerebeek, K. 2007. Bushmeat and bycatch: the sum of the parts. Mol. Ecol. Notes 16: 2607-09.

Clark, D.B. 2019. The Last Whalers: The Life of an Endangered Tribe in a Land Left Behind. John Murray Press, London. 368pp.

Collins, T., Cerchio, S., Pomilla, C., Loo, J., Carvalho, I., Ngouessono, S. and Rosenbaum, H.C. 2008. Revised estimates of abundance for humpback whale breeding stock B1: Gabon. Document SC/60/SH28 presented to the IWC Scientific Committee, Santiago, Chilé (unpbublished). 48pp. [Paper available from the Office of this Journal]

de Boer, M.N., Saulino, J.T., Van Waerebeek, K. and Aarts, G. 2016. Under pressure: Cetaceans and fisheries co-occurrence off the coasts of Ghana and Côte d'Ivoire (Gulf of Guinea). Frontiers in Marine Science 3(178). [Available at: https:/doi.org/110.3389/fmars. 2016.00178].

Déruelle, B., Moreau, C., Nkoumbou, C., Kambou, R., Lissom, J., Njonfang, E., Ghogomu, R.T. and Nono, A. 1991. The Cameroon Line: A Review. pp.274-327. In: Lubala, A.B.K.a.R.T. (eds). Magmatism in Extensional Structural Settings. Springer, Berlin. i-xxviii+637pp.

Fielding, R. 2010. Environmental change as a threat to the pilot whale hunt in the Faroe Islands. Polar Res 29: 430-8. [Available at: https://doi.org/10.1111/j.1751-8369.2010.00168.x].

Fielding, R. 2018. The Wake of the Whale: Hunter Societies in the Caribbean and North Atlantic. Harvard University Press, Boston.

Football Kit Archive. 2020. FC Barcelona Kit Archive. [Available at: https://www.footballkitarchive.com/fc-barcelona-kits/Accessed 4 June 2020].

Fuchs, C. and Horak, E. 2008. Africa and the digital divide. Telemat. Inform. 25: 99-116.

Hagemeijer, T. and Zamora, A. 2016. Fa d'Ambô: From past to present. Int. J. Soc. Lang. 239: 193-209. [Available at: https://doi.org/ 10.1515/ijsl-2016-0009].

Hamaguchi, H. 2005. Use and Management of Humpback Whales in Bequia, St. Vincent and the Grenadines. pp.87-100. In: Kishigami, N. (eds). Indigenous Use and Management of Marine Resources. National Museum of Ethnology, Osaka.

Instituto Nacional de Estadística de Guinea Ecuatorial. 2015. Censo de Población 2015 - República de Guinea Ecuatorial. [Available at: http://www.inege.gq/ Accessed 4 June 2020].

International Whaling Commission. 2018. Schedule as amended by the Commission at the 67th Annual Meeting, Florianopolis, Brazil, September 2018. [Available from the Office of this Journal]

Johnson, R.M. 2000. The last whale hunters. Maritime Life and Traditions (8): 44-61.

Kaplan, D. 2011. Some tips for improving Spanish-to-English legal translations. Mutatis Mutandis 4(2): 287-93.

Neufield, W. 1973. The Last Whalers. WBN Productions, Plainfield, New Jersey, 16mm film. [Available at: https://vimeo.com/36922756 Accessed 4 June 2020].

Pereira, F. and Ebrahimi, T. 2002. The MPEG-4 Book. Prentice Hall Professional, Upper Saddle River, New Jersey. 849pp.

Picanço, C., Carvalho, I. and Brito, C. 2009. Occurrence and distribution of cetaceans in São Tomé and Príncipe tropical archipelago and their relation to environmental variables. J. Mar. Biol. Assoc. UK 89(5): 1071-76. 
Robards, M.D. and Reeves, R.R. 2011. The global extent and character of marine mammal consumtion by humans: 1970-2009. Biol. Conserv. [Available at: $h$ ttps://doi.org/10.1016/j.biocon.2011.07.034].

Rodríguez-Fonesca, J. and Garita-Alpízar, F. 2013. Dolphins of the coastal Central Pacific of Costa Rica (from Matina to Puerto Limón). Diversity and seasonal distribution. Paper SC/65a/SM04rev presented to the IWC Scientific Committee, June 2013, Jeju Island, Republic of Korea (unpublished). 12pp. [Paper available from the Office of this Journal].

Rosenbaum, H.C. and Collins, T. 2006. The ecology, population characteristics and conservation efforts for humpback whales (Megaptera novaeangliae) on their wintering grounds in the coastal waters of Gabon. pp.425-33. In: Alonso, A. and Campbell, P. (eds). Natural History of the Gamba Complex. Smithsonian Press, Washington, DC.

Skutsch, C. 2013. Encyclopedia of the World's Minorities. Routledge, London.

Smith, R.C. 2013. Last of the Viking whalers. National Geographic 223(6). [Available at: https://www.nationalgeographic.com/ magazine/2013/06/viking-whalers/ Accessed 4 June 2020].

Townsend, C.H. 1935. The distribution of certain whales as shown by logbook records of American whaleships. Zool. Sci. Contrib. N. Y. Zool. Soc. 19(1-2): 1-50+6 maps.

Valenciano-Mañé, A. 2017. The Clothes of Extraversion: Circulation, Consumption and Power in Equatorial Guinea. Ph.D. thesis, University of Barcelona, Spain.

Van Waerebeek, K., Ofori-Danson, P.K. and Debrah, J. 2009. The cetaceans of Ghana: a validated faunal checklist. West Afr. J. Appl. Ecol. 15: 6190. [Available at: $h$ ttps://doi.org/10.4314/wajae.v15i1.49428].

Van Waerebeek, K., Tchibozo, S., Montcho, J., Nobime, G., Sohou, Z., Sehouhoue, P. and Dossou, C. 2001. The Bight of Benin, a North Atlantic breeding ground of a Southern Hemisphere humpback whale population, likely related to Gabon and Angola substocks. Paper SC/53/IA21 presented to the IWC Scientific Committee, July 2001, London (unpublished). 8pp. [Paper available from the Office of this Journal].

Ward, N.F.R. 1995. Blows, mon, blows! 1st ed. Gecko Publications, Woods Hole, MA. 56pp.

Warf, B. 2019. Geographies of Sub-Saharan African Corruption. pp.111-41. In: Warf, B. (eds). Global Corruption from a Geographic Perspective. Springer, Cham, Switzerland.

Weir, C.R. 2011. Distribution and seasonality of cetaceans in tropical waters between Angola and the Gulf of Guinea. Afr. J. Mar. Sci. 33(3): 1-15. [Available at: $h$ ttps://doi.org/10.2989/1814232X.2011.572333].

Weir, C.R. and Pierce, G.J. 2012. A review of the human activities impacting cetaceans in the eastern tropical Atlantic. Mamm. Rev. 43: 258-74. [Available at: https://doi.org/10.1111/j.1365-2907.2012.00222.x].

Weston, T. 2014. The Wind That Blows: A Portrait of the Last Yankee Whalers. Grenadines Motion Picture Company, Bequia, St. Vincent \& the Grenadines, DVD format. 